Cronfa - Swansea University Open Access Repository

This is an author produced version of a paper published in :

Race \& Class

Cronfa URL for this paper:

http://cronfa.swan.ac.uk/Record/cronfa33865

\title{
Paper:
}

Burnett, J. (2012). After Lawrence: racial violence and policing in the UK. Race \& Class, 54(1), 91-98.

http://dx.doi.org/10.1177/0306396812444830

This article is brought to you by Swansea University. Any person downloading material is agreeing to abide by the terms of the repository licence. Authors are personally responsible for adhering to publisher restrictions or conditions. When uploading content they are required to comply with their publisher agreement and the SHERPA RoMEO database to judge whether or not it is copyright safe to add this version of the paper to this repository. http://www.swansea.ac.uk/iss/researchsupport/cronfa-support/ 


\section{After Lawrence: racial violence and policing in the UK}

Abstract: As the UK celebrates the conviction of two men for the racist murder nineteen years ago of Stephen Lawrence, the author draws on research into racial violence being carried out by the Institute of Race Relations to show that violence is still at very high levels and becoming dispersed to new areas. The Macpherson report may have brought in changes to police practices, but violent popular racism, encouraged by larger government policies, such as the war on terror, is still a national scandal.

Keywords: Islamophobia, Macpherson, Plymouth, policing, racist murders, Stephen Lawrence, Stoke-on-Trent

On 3 January 2012, Gary Dobson and David Norris, were found guilty of the murder of black teenager Stephen Lawrence, almost nineteen years after he was stabbed to death in an unprovoked racist attack in south-east London. The response to this conviction within the UK was unprecedented, with extensive, round-the-clock reporting of the sentencing and a resurgence of interest in the details of the case and the painstaking collection of forensic evidence that had been able to place the murderers at the scene.

That the conviction of these two men provoked so much scrutiny was down to the way that Stephen's death had come to personify racial violence in the UK. But the political significance of his case went well beyond the attack itself. (Racist murders, after all, were relatively frequent in 1993; and Eltham, where he was killed, was well-known as a racist hotbed.) Rather, the murder came to take on such significance because of the tireless campaigning of his parents who, in their long battle to bring to account his killers, confronted headon official incompetence and denial: from the initial failure of the police to follow up on leads by people well aware who the murderers were, to the way that police refused at first to recognise any racist element in the killing, to the way that Stephen's friend who witnessed the attack was, on the basis of his ethnicity, stereotyped as a protagonist in the violence. ${ }^{1}$ Theirs was a struggle which, ultimately, led to a public inquiry into police handling of the case and the publication of the Macpherson Report in 1999 with its damning assessment 
of a police force infused with institutional racism. It, in turn, led to the Race Relations (Amendment) Act 2000 and a change to the law on double jeopardy which opened up the possibility of a retrial of some of the men strongly suspected to have been involved in the murder (including Dobson, who was eventually convicted).

Such was the tenacity of the Lawrences' campaigning that the conviction was celebrated as a shared national victory: by the press which, somewhat late in the day, had come to back them, by the politicians who had pushed for an inquiry into the death and, significantly, by the same criminal justice agencies which had initially so cruelly failed them. For many, the conviction of Dobson and Norris signified redemption and the perception that much had changed. The police said that many of the seventy specific recommendations made in the Macpherson Report have permeated criminal justice practice. Cressida Dick, acting deputy of the Metropolitan Police, announced how the force 'can be proud of how it has been transformed in attitudes, practice, training and professionalism'. ${ }^{2}$ The Prime Minister, meanwhile, although conceding that there was still a 'problem of people from different racial backgrounds being disadvantaged in Britain', claimed that the UK was 'less racist' than at the time of Stephen's death. ${ }^{3}$

Yet despite this surge of congratulatory rhetoric, the routine racist attacks, the harassment, abuse and violence experienced by thousands of people from black and minority ethnic (BME) communities each year, have remained almost entirely absent from the political agenda. The number of racist incidents reported by the police increased almost five-fold between 1993 and 2011, from 10,997 to 51,187, with almost no acknowledgment aside from claims by the police that this is simply a reflection of better recording practices. Of these, at least ninety-six (about five per year) have been murders with a known or suspected racial element, and forty people have lost their lives as Stephen did as a result of unprovoked racist attacks on the streets. Overwhelmingly, those killed in racist attacks have been males under the age of thirty. Nineteen people relatively 'new' to the UK - as asylum seekers, migrant workers or visitors, for example - have been murdered with one, Anuj Bidve, an Indian student, shot in the head in Salford as he walked early one morning to the post-Christmas sales, just a week before two of Stephen's killers were convicted. Seven people (including a 4-year-old child) have been killed in their homes in arson or 
firebomb attacks and sixteen people have died as a result of being attacked at work. Out of the total number of people who have lost their lives as a result of racial violence, some cases, such as the savage axe-murder of Anthony Walker in Liverpool in 2005, made national headlines, but the vast majority passed by virtually unnoticed except by the families whose lives were torn apart by their loss. ${ }^{4}$

\section{Shifting patterns of racial violence}

Rather than stumbling towards a 'less racist' country, the years following the death of Stephen Lawrence have been marked by new forms of racism against new targets - underscored by government policies and practices and manifested as attacks on the streets, in work-places and against people in their homes. In almost two decades, the parameters of racial violence have broadened in scope and geography. And whereas a few decades ago the majority (although by no means all) of attacks were concentrated in larger urban areas, racial violence now extends to smaller cities, towns and rural districts.

Of course, this is not to deny the long history of racial violence in rural areas. In the early 1990s, for example, the then Commission for Racial Equality (CRE) documented in painstaking detail the grim day-to-day reality of racism in the south-west. ${ }^{5}$ But as demographics have changed and particular areas have become more 'diverse', racist attacks, in some localities, have become entrenched. For many politicians the answer is simply to set a limit on immigration to better 'race relations'.

But this ancient adage conveniently ignores the fact that racism is shaped by government policies - though its impact locally may be underpinned by specific contexts and histories. In Stoke-on-Trent, for instance, a city ravaged by deindustrialisation and with over half of its residents defined as living in the most deprived quintile in England, the proportion of residents from a BME background has more than doubled in the last two decades. This swift population change occurred as many white families, with the resources and wherewithal, left the city. And, in turn, the racist attacks which began to occur with increasing regularity and ferocity at the beginning of the twenty-first century (by 2005, a third of those residents from BME communities had experienced some form of racial harassment in the previous three years) have to be understood in terms of an increasingly hostile political climate exploited by 
local politicians for electoral gain. Stoke provides a stark illustration of the consequences of what happens when mainstream politics accommodates the messages of the far Right, whilst at the same time abandoning those communities which the far Right targets to garner support. By 2008, there was a credible possibility (eventually not realised) of the city council becoming the first in the UK to be controlled by the British National Party (BNP).

In Plymouth, meanwhile, in the south-west, increasing attacks, especially on asylum seekers, overseas students and BME families moving into hitherto white neighbourhoods, have been met by official denial. In a military city where the local economy has been decimated as a result of its declining dockyards, racist attacks reached such a point that, in 2003, one investigation by the Observer dubbed the locality 'the city of hate'. ${ }^{6}$

In such contexts, the developments of new forms of racism have proved fatal. Take, for example, the case of Firsat Dag, an asylum seeker who, in 2001, was stabbed to death in a racist attack as he was walking to his house in Glasgow. Firsat had been sent to the Sighthill estate, an impoverished area of the city (now demolished and rebuilt) then used as a dumping ground for the poor and the dispossessed. It was well known at the time for racist attacks, especially against the increasing numbers of asylum seekers who were being dispersed there in an attempt to reduce the financial and social 'burden' of providing accommodation in the south-east of Britain. Firsat's death has to be seen against the backdrop of the concerted media campaign targeting the presence of 'parasitic' asylum seekers; a campaign that both reinforced and was reinforced by a political climate within which mainstream parties vied with each other as to which could be tougher 'on asylum'. According to one investigation, dispersal policies, in practice, were leading to the dispersal of xenophobia. ${ }^{7}$ And such was the level of concern about the danger facing asylum seekers that in 2004 the government effectively dismantled the policy, temporarily stopping sending people to certain towns and cities on the advice of local police. ${ }^{8}$ This action came far too late for Firsat though. As it did for Peiman Bahmani, stabbed to death in Sunderland in 2002; Mohammed Isa Hassan, beaten to death in Southampton in 2003; and Kalan Kawa Karim, a man who arrived in the UK disabled as a result of torture in Iraq and was murdered in Swansea in 2004.

But, of course, the thousand of racist attacks taking place each year have not been confined to those seeking asylum. In the first decade of the twenty-first 4 
century, with Muslims in the UK cast as a new enemy within in the context of the 'war on terror', they became, according to the sociologists Simon Pemberton and Christina Pantazis, a new suspect community. ${ }^{9}$ And this is a community which has been subjected to a surge of violence and harassment. One person targeted, just a few days after the 7/7 terrorist bombings in London, was Kamal Raza Butt, a man visiting friends and family in Nottingham. On his way to a shop to buy cigarettes he was set upon by youths who reportedly shouted 'Taliban' at him before beating him to death. Attacks against Muslims increased by 500 per cent in the immediate aftermath of the 7/7 bombings, according to the Muslim Safety Forum, with over 170 incidents recorded in two weeks. ${ }^{10}$ And this campaign of harassment and abuse has shown few signs of abating. Of 1,200 anti-Muslim attacks reported to the police in 2010, examples included serious assaults, the desecration of gravestones and the petrol-bombing of mosques. ${ }^{11}$

Forty-four Muslims have lost their lives since 1993 in murders with a known or suspected racial element. Some, such as Kamal, were killed as a direct result of the Islamophobia and specific anti-Muslim racism exacerbated through the war on terror. Many others though were murdered in alcohol-fuelled racist attacks whilst at work in the night-time economy. Over the past four decades, this section of the economy has grown substantially as towns and cities devastated by deindustrialisation have encouraged new forms of investment, frequently through a relaxation of licensing laws. As such, a form of economic restructuring has taken place within which those from certain BME communities are often employed in subsidiary industries - as cab drivers, in takeaways, in fast food outlets and in service stations. These are industries characterised by flexible, non-unionised working conditions, with workers isolated, vulnerable to abuse and bearing some of the true costs of politicians' boasts of light-touch regulation. Israr Hussain, for example, was killed after being stabbed through the neck in his taxi in 2002 after an altercation with a customer in Oldham. Mohammed Pervaiz died in 2006 in Huddersfield after being set upon in his cab by a gang of youths shouting, according to witnesses, racist abuse. And it is not just Asians and Muslims at risk of attack in such industries. Paul Rosenburg, a South-African taxi driver in the Isle of Wight died in 2003 after being stamped on repeatedly by a man who later confessed to a friend that 'I only did it because he is Black'. 
The point, here, is not just that different groups of people face risk of attack, but that the particular economic, political, domestic and international policies adopted by governments, in the nineteen years since Stephen Lawrence was killed, have both underpinned and exacerbated the formation of new patterns of racism and racial violence. But instead of analysing the local racial fallout from say asylum policy or the wars in Afghanistan and Iraq, politicians and opinion-formers turn the tables and define problems in terms of mistrust and antagonism between individuals in communities which do not cohere because of 'self-segregation'.

In the aftermath of a series of urban disorders in 2001, predominantly between Asian youths, white people and the police, a new policy agenda of community cohesion was established which, essentially, argued that racism surfaced in a context of communities leading 'parallel lives'. The Asian and white communities who resided in towns and cities like Burnley, Bradford and Oldham, where rioting had taken place, lived, it was said, in enclaves where they never met each other in any meaningful way. As a result, what was required was a set of core values and a common, shared vision which would create the capacity for cohering identities. What was at stake was a recasting of citizenship, one in which rights had to be matched with responsibilities and the government had to refocus its energies into promoting integration so as to counter the effects of a country which, it was said, was marred by segregation. ${ }^{12}$ And so it was only a natural progression for this to morph into an emergent call for the championing of Britishness: popularised first by Gordon Brown when he was Prime Minister and, more recently, by an array of political commentators and policy think-tanks eager to assert a 'new' national identity. So, too, it was also a natural progression for this in turn to morph into an attack on multiculturalism. Thus, according to Cameron, in a barely concealed lambast against Muslims, 'the doctrine of state multiculturalism' has failed - it is a divisive ideological project which has led to communities self-segregating, the undermining of national identity and, ultimately, to a growth of extremism which has been left unchecked. ${ }^{13}$

\section{Policing in the aftermath of the Macpherson Report}

What this shift means today is that the progressive message within the Macpherson Report has been undermined and any political gains rolled back at exactly the time that new forms of racism have emerged and been percolated 
through a series of government policies. On the ground, this has impacted upon a police force which, despite being lauded as radically transformed as a result of Macpherson, in rank-and-file reality resents the term 'institutional racism' according to research conducted on behalf of the Home Office. ${ }^{14}$ And, in this context, many of the aspects of policing which were critiqued most vocally by Macpherson have continued regardless, exacerbated and reproduced in the routine interactions between BME communities and the police.

The most visible of these is stop-and-search. Macpherson was not against the use of stop-and-search per se, but did highlight that the discriminatory use of the power increased tensions between particular communities and the criminal justice system. Regardless of this though, stops have massively increased. In 1999, black people were 5.9 times more likely to be stopped and searched than white people under powers contained within Section 1 of the Police and Criminal Evidence Act 1984 (PACE). In 2009/10, this disparity had risen to seven times more likely. ${ }^{15}$ Moreover, with regard to powers where the police are not required to prove reasonable suspicion of a person having committed an offence, disproportionality is much, much starker. In 2011, black people were nearly thirty times more likely to be stopped and searched under Section 60 of the Criminal Justice and Public Order Act 1994 than white people, leading to accusations of increasing 'racial profiling'. ${ }^{16}$ But this is an accusation that has been increasingly difficult to prove with regard to stop-and-search (though no less true), after several police forces took advantage of the Home Office's removal of the requirement to record 'stop-and-accounts' (where police stop people and require them to account for their whereabouts) under the auspices of cutting back on police bureaucracy. ${ }^{17}$

And what of racial violence? Cressida Dick says that more than half of the racist incidents recorded in the UK are now detected by the criminal justice system and that BME communities now have nearly as much confidence in the police as do other communities. But has the police understanding of racism, how it manifests itself in populist violence and how the police themselves contribute to racism, undergone change all the way through the force?

The family of Shahid Aziz, a 30-year-old man in Armley prison who was murdered in 2004 by his cell-mate who slit his throat and beat him with a chair leg as he lay dying, faced a police alleging that there was no racist element to the killing. And this despite the fact that the killer had objected to Shahid 
speaking in his own language and of having to share a cell with an Asian man. Or what about the partner of Mi Gao Huang Chen, who claims that the campaign of racial abuse they were subjected to in Wigan was ignored by the police in 2004 until finally, her partner was killed? These are not the only cases where families have had to confront an official denial of racism in chilling echoes of the Lawrences' long fight for justice. And surely, the starkest reminder of just how antagonistic relations are between the police and many people from BME communities is the riots which swept through England in summer 2011. One of the most common explanations for the actions of those who took part was the inequities of stop-and-search and a sheer hatred of police overlordship.

Such realities tear down the carefully cultivated façade that this is a country that has eliminated racism from the workings of its institutions. They explode the fallacy that racial violence is becoming less frequent. The perception that, after Macpherson, such racism declined, being steadily eradicated by the criminal justice system, is, simply, a lie.

\section{References}

\footnotetext{
${ }^{1}$ Benjamin Bowling and Coretta Phillips, Racism, crime and justice (London, Longman, 2002), pp. 15-16.

${ }^{2}$ Cressida Dick, 'Stephen Lawrence murder: nothing in the Met's history had a greater impact', Guardian (3 January 2012), http://www.guardian.co.uk/global/2012/jan/03/cressida-dick-stephen-lawrence-verdicts Incidentally, Cressida Dick was the officer who, in 2005, was in charge of the operation which led to the killing of Jean Charles de Menezes, an entirely innocent Brazilian man , wrongly suspected of involvement in terrorist activities, shot eight times by police officers on the London underground. Cressida Dick has since been promoted.

3 Donna Bowater, 'David Cameron: Britain “still has a problem with racism”', Daily Telegraph (9 January 2012), http://www.telegraph.co.uk/news/uknews/law-and-order/9002758/David-Cameron-Britain-still-has-aproblem-with-racism.html

${ }^{4}$ Institute of Race Relations, '96 murders since Stephen Lawrence's', Institute of Race Relations (5 January 2012), http://www.irr.org.uk/2012/january/ha000002.html All of the murders cited in this article are detailed further in: Institute of Race Relations, 'Deaths with a (known or suspected) racial element 1991-1999', IRR Factfile (22 April 2010), http://www.irr.org.uk/2002/november/ak000002.html; and Institute of Race Relations, 'Deaths with a (known or suspected) racial element 2000 onwards', IRR Factfile (5 January 2012), http://www.irr.org.uk/2002/november/ak000008.html

${ }^{5}$ Eric Jay, 'Keep them in Birmingham': challenging racism in south-west England (London, Commission for Racial Equality, 1992).

${ }^{6}$ For information on racial violence in both of these cities see Jon Burnett, The new geographies of racism: Plymouth (London, Institute of Race Relations, 2011); and Jon Burnett, The new geographies of racism: Stokeon-Trent (London, Institute of Race Relations, 2011).

${ }^{7}$ Liz Fekete, The dispersal of xenophobia (London, Institute of Race Relations, 2000).

${ }^{8}$ Blaise Tapp, 'Curb on the asylum seekers', Manchester Evening News (15 November 2004), http://menmedia.co.uk/manchestereveningnews/news/s/136/136915 curb on the asylum seekers.html 
${ }^{9}$ Christina Pantazis and Simon Pemberton, "From the "Old" to the "New" Suspect Community: Examining the Impacts of Recent UK Counter-Terrorist Legislation', British Journal of Criminology (Vol. 49, No. 5, 2009), pp. 646-666.

${ }^{10}$ BBC, 'Hate crimes "rise after UK bombs"', BBC News (28 July 2005),

http://news.bbc.co.uk/1/hi/uk/4723339.stm

${ }^{11}$ Andrew McCorkell, 'Muslims call for action against hate crimes', Independent (12 June 2011), http://www.independent.co.uk/news/uk/crime/muslims-call-for-action-against-hate-crimes-2296477.html

12 Ted Cantle, Community cohesion: a report of the independent review team (London, Home Office, 2001).

${ }^{13}$ David Cameron, Speech to the Munich Security Conference, (5 February 2011),

http://www.number10.gov.uk/news/pms-speech-at-munich-security-conference/

${ }^{14}$ Janet Foster, Tim Newburn and Anna Souhami, Assessing the impact of the Stephen Lawrence Inquiry, Home Office Research Study 294 (London, Home Office, 2005).

${ }^{15}$ Mark Townsend, 'Abuse of stop-and-search powers is a crime, says Lawrence advisor', Guardian (7 January 2012), http://www.guardian.co.uk/law/2012/jan/07/abuse-stop-search-crime-police

${ }^{16}$ Mark Townsend, 'Stop-and-search "racial profiling" by police on the increase, claims study', Guardian (14 January 2012), http://www.guardian.co.uk/law/2012/jan/14/stop-search-racial-profiling-police

${ }^{17}$ Vikram Dodd, 'Police forces cease recording race of people they stop', Guardian (22 September 2011), http://www.guardian.co.uk/uk/2011/sep/22/police-record-race-stop 